Karras J. Lambert, Christopher J. Coyne* and Nathan P. Goodman

\title{
The Fatal Conceit of Foreign Intervention: Evidence from the Afghanistan Papers
}

https://doi.org/10.1515/peps-2021-0001

Received January 1, 2021; accepted April 14, 2021

Abstract: The fatal conceit of foreign intervention refers to the limitations faced by governments using discretionary power to address perceived problems in foreign societies. Drawing on evidence from the "Afghanistan Papers"-a collection of internal government documents compiled by the Special Inspector General for Afghanistan Reconstruction (SIGAR) and released in December 2019-we demonstrate how the failure of the U.S.-led intervention in Afghanistan to meet the stated objectives illustrates the fatal conceit of foreign intervention. We explore the limitations faced by foreign government interveners in three stages, reflecting distinct decision nodes within a means-ends framework in which the policies relating to foreign intervention are formulated and implemented.

Keywords: Afghanistan, Afghanistan Papers, fatal conceit, foreign intervention, nation building

JEL codes: D73, F50, H56

\section{Introduction}

Can governments effectively produce sustainable change toward liberal democratic institutions in foreign societies through military occupation? This paper contributes to answering this question by presenting evidence contained within the "Afghanistan Papers," a collection of 612 internal documents obtained from the Special Inspector General for Afghanistan Reconstruction (SIGAR) by The Washington Post and released publicly on December 9, 2019. The documents consist of 424 "Lessons Learned" interviews conducted by SIGAR between 2014 and 2018 as

\footnotetext{
*Corresponding author: Christopher J. Coyne, Department of Economics, George Mason University, MSN 3G4, Fairfax, VA, 22030, USA, E-mail: ccoyne3@gmu.edu Karras J. Lambert and Nathan P. Goodman, Department of Economics, George Mason University, MSN 3G4, Fairfax, VA, 22030, USA, E-mail: klamber7@gmu.edu (K.J. Lambert), ngoodman@gmu.edu (N.P. Goodman)
} 
well as 188 "snowflake" memos (short internal memoranda) addressed from or to former U.S. Secretary of Defense Donald Rumsfeld between 2002 and 2004.

Information contained within the Afghanistan Papers provides unique insight into the dynamics of the U.S. occupation in Afghanistan, which began in October 2001 under the broader "Operation Enduring Freedom" mission. The mission in Afghanistan included four phases. The first involved targeted strikes by special forces. This was followed by air strikes (phase 2) and ground troops (phase 3) targeting the Taliban and al Qaeda while providing humanitarian aid. The final phase entailed U.S. efforts to "stabilize the country and help the Afghan people build a free society” (Bush 2010: 194). While the U.S. government achieved some of its objectives in the first three phases, the final phase has failed.

The Costs of War project at Brown University estimates that, between 2001 and 2019, approximately $\$ 2$ trillion has been spent on the war in Afghanistan, with nearly $\$ 1$ trillion in Defense and State Department appropriations (Costs of War 2019). Despite such massive federal outlays, evidence from the Afghanistan Papers indicates that the U.S. and NATO-led attempt to reconstruct Afghanistan and drive out the Taliban has not achieved those aims, but has instead generated massive waste, corruption, and dysfunction. In light of this, Afghan public sector specialist Michael Callen told SIGAR in an October 2015 interview that "the writing is on the wall now. We spent so much money and there is little to show for it."1

The central argument of this paper is that the evidence contained in the Afghanistan Papers illustrates the "fatal conceit of foreign intervention." The "fatal conceit" refers to the presumption that "man is able to shape the world around him according to his wishes" (Hayek 1988: 27). Extending this idea internationally, the fatal conceit of foreign intervention refers to the limitations of "the use of discretionary power of one government to address perceived problems in foreign societies" (Coyne and Mathers 2010: 27). The fatal conceit of foreign intervention is characterized by several features. These features include a reliance on top-down planning, the allocation of resources through bureaucratic political channels, the approach towards economic development as a technological issue, and the treatment of societies as simple rather than complex systems.

We contribute to the literature exploring U.S. foreign military interventions aimed at institutional nation-building in other societies. These interventions seek to close the "sovereignty gap," which refers to the disconnect between the assumption that all states are sovereign entities and the inability of weak and failed to engage in effective governance (Ghani and Lockhart 2008: 3). This literature finds more failures than successes in U.S.-led nation-building efforts and analyzes the various factors and mechanisms driving this variation in outcomes

1 callen_michael_ll_02212018. 
(Berger et al. 2013; Bueno de Mesquita and Downs 2006; Coyne 2008a, 2011; Coyne and Mathers 2010; Coyne and Pellillo 2011; Denison 2020; Downes and Monten 2013; Duncan and Coyne 2015; Enterline and Greig 2005, 2008; Payne 2006; Pickering and Peceny 2006). The scholarship in this area identifies a range of epistemic constraints, incentives, and unanticipated consequences which place limits on what foreign military interventions can accomplish in practice. We draw on the first-hand information contained within the Afghanistan Papers to provide evidence of these constrains and their manifestation in the U.S. government's occupation of Afghanistan. We catalog and present the main themes from the Afghanistan Papers with an appreciation that a key "task of economics is to demonstrate to men how little they really know about what they imagine they can design" (Hayek 1988: 76). In doing so we contribute to a related, but distinct, strand of literature exploring efforts at state building in Afghanistan (Murtazashvili 2016; Murtazashvili and Murtazashvili 2019, 2020, 2021). This literature focuses on the flawed U.S. intervention in Afghanistan, with particular focus on the problems caused by incentive and information issues. Our analysis builds on, and complements, this existing scholarship.

In what follows, we explore the limitations faced by U.S. government and NATO allies in attempting to construct liberal democratic institutions in Afghanistan by dividing the analysis into three stages. These stages reflect distinct decision nodes within a means-ends framework in which the policies relating to foreign intervention are formulated and implemented. First, there are epistemic and practical challenges at the level of selecting the ends to be pursued (Section 2). Second, there are issues related to the selection and implementation of the appropriate means to attain chosen ends due to the absence of market feedback mechanisms as well as the incentives inherent in bureaucratic organization (Section 3). Finally, after interventions are implemented, system effects often produce unanticipated consequences that are counterproductive to or entirely at odds with the ends originally sought (Section 4). Section 5 concludes with a discussion of implications of the fatal conceit of foreign intervention in practice.

\section{Goal Formation (Selection of Ends)}

\subsection{Aligning Policy Goals with the Welfare of the Intervened- Upon}

Foreign intervention requires decision makers in the intervening country to identify problems in a foreign society and decide which goals will be pursued 
during the intervention. The intended outcomes of interventions vary but, at least rhetorically, typically include some mix of immediate humanitarian assistance, longer-term development, and permanent change toward liberal institutions. The common theme across interventions is that the end stated by interveners is to improve the welfare of the populace being intervened upon. While the military intervention in Afghanistan has from the beginning been primarily concerned with countering insurgency groups and terrorist organizations, former U.S. President George W. Bush stated in a speech as early as 2002 that the goals of continued intervention in Afghanistan involved "full commitment to a future of progress and stability for the Afghan people" as well as helping Afghanistan "claim its democratic future" so that Afghan citizens might enjoy equal rights, education, health care, and the eradication of disease and hunger (Bush 2002).

No matter how laudable such goals are in the abstract, interventions that fail to align resource allocation decisions with the goals and values of the individuals in the population being intervened upon are unlikely to produce sustainable results. Since state-led foreign interventions require operating through bureaucratic political channels and often involve partnership with the state apparatus in the foreign society, policymakers cannot access the private valuations of the local population in the society being intervened upon. Therefore, such policymakers must at best formulate and act upon what they believe individuals in the foreign society would want with the resources involved in the intervention. At worst, planners in one society may seek to impose their own hierarchy of ends, irrespective of the plans and values of the individuals living in the foreign society.

While George W. Bush (2002) did state that he wished to see Afghanistan develop "in their image, not in ours," some participants in SIGAR lessons learned interviews indicated that this was rarely the case. During the course of one anonymous British official's experience in Afghanistan, "The elephant in the room was that there were no Afghans in the room."2 "It wasn't like there was a lot of thought given to how we can make sure that this results in something that's actually valuable ... that is socially for the people it's serving that is sustainable," Afghan public sector specialist Michael Callen stated in a 2018 interview. $^{3}$ One former National Security Council staffer noted how those working on the ground in Afghanistan "would talk to Afghans and realize you weren't getting them the things they need." ${ }^{4}$ He notes that while the Afghans were receiving "beautiful new schools," they really needed "teachers to show up at those schools" and "salaries for the teachers.” Another anonymous U.S. Special Forces advisor concurred,

2 background_ll_04_xx_09232016.

3 callen_michael_ll_02212018.

4 background_ll_01_xx_phone_01052015. 
recalling how a Provincial Reconstruction Team (PRT) "thought development was just giving people money. Building schools where there are no students." ${ }^{5}$ The same interviewee also said that many of the activities undertaken by the PRT "weren't created from any demand signal" and were ideas that "would have worked 75 years ago in the United States," not necessarily in present-day Afghanistan. ${ }^{6}$

Tariq Esmati, a native Afghan and former Afghan Deputy Cabinet Minister of Rural Development, distinguished "symbolic development" from "systematic development."7 While symbolic development involved simply "to show ... the government or high officials that you are there and doing something," systematic development requires sensitivity to "the need of the society" and to "respond to it step by step." To support his point about U.S. agencies pursuing symbolic rather than systematic development, Esmati recalled how individuals working for the U.S. Agency for International Development (USAID) would exclude him from meetings in which prospective solutions to issues involving local instability were discussed. According to Esmati, USAID officials would eventually issue an assessment "done in a way to fit the package of the implementer but it didn't match the needs of the people."

The challenge is even greater than Esmati's quotes suggest. Murtazashvili (2016) argues that both foreign and domestic bureaucrats in Afghanistan failed to respect local institutions. The Ministry of Rural Rehabilitation and Development (MRRD) is a national government bureaucracy, and Murtzashvili shows that the MRRD suffered from the fatal conceit by ignoring customary governance institutions in Afghanistan. It was not just that the foreign interveners were engaged in symbolic development, but so too were many Afghan agencies and bureaucrats. In many cases the lack of success was not an issue of Afghans being entirely excluded from the process, but rather that those who were included often lacked the required nuanced knowledge- based on customary and self-governing associations-to represent the interests of the local populace (Murtazashvili 2016; Murtazashvili and Murtazashvili 2019, 2020, 2021).

According to individuals interviewed by SIGAR, the approach towards the intervention in Afghanistan seems to have involved an even more gross unfamiliarity with the region and local culture. One former USAID official recalled how

5 background_ll_05_xx_phone_01222016.

6 We should note that not all aid and assistance programs failed in Afghanistan, as some did successfully achieve their goals (see, Beath, Christia, and Enikolopov 2013, 2015). On the crucial difference between achieving output targets and achieving sustainable development, see Coyne 2013.

7 esmati_tariq_ll_12122016. 
"there were very few people who understood how the Afghan mind works ... not too many people who really understood Afghanistan or speak Dari well enough to carry themselves." 8 Douglas Lute, White House war czar for Afghanistan between 2007 and 2013 and former U.S. ambassador to NATO, agreed, stating in his 2015 lessons learned interview with SIGAR that "we were devoid of a fundamental understanding of Afghanistan - we didn't know what we were doing. What are the demographics of the country? The economic drivers?" Tooryalai Wesa, a former Afghan governor of Kandahar province, argued that programs should be designed locally in Afghanistan and not in Washington, D.C. and recalled how one stability program "prioritized a project to teach people how to wash their hands," which "was an insult to the people" since they "wash their hands five times a day for prayers." Meanwhile, Dr. Thomas Johnson, Professor at the Naval Postgraduate School and an Afghanistan specialist, declared "the number one lesson" that should be learned from the intervention to be that the U.S. policymakers and forces "just did not understand the environment." 11 This is consistent with arguments for a "citizen-based approach" to state-building, which holds that sustainable governance institutions require the ongoing participation and involvement of those living within those institutions (see Ghani and Lockhart 2008: 7; Ostrom 2000).

Some interviewees found the top-down process through which government institutions were created during the early stages of the reconstruction of Afghanistan, including the constitution drafted in Bonn, Germany in December 2001 as well as the more general attempt to impose democratic institutions within Afghanistan, to be misguided and doomed to failure. Michael Callen expressed his belief that "many of the problems go all the way back to the initial drafting of the constitution, describing it as a "political bargain" and an "ad hoc process to keep everybody sitting at the Bonn conference happy."12 An anonymous U.S. official stated that the U.S. "should have built our assistance and government based on tribal structures," noting, "Afghanistan has never had a tradition of governance by democracy" and that the U.S. government "cannot export democracy" to a country that lacks such a tradition. ${ }^{13}$ Retired U.S. Army general Dan McNeill "tried to get someone to define ... what winning meant" but "never could," instead finding that

\footnotetext{
8 background_ll_01_xx_dc_05052015.

9 lute_doug_ll_01_d5_02202015.

10 wesa_toryalay_ll_01072017.

11 johnson_thomas_ll_01072016.

12 callen_michael_ll_02212018.

13 background_ll_01_xx_carlisle_10292015 Some in the U.S. military were aware of the importance of social and customary sources of authority in Afghanistan (see, for instance, Gant 2014). This, however, has been a minority position in the broader U.S. intervention in Afghanistan.
} 
"some people were thinking in terms of Jeffersonian democracy," which McNeill believes is "just not going to happen in Afghanistan."14

These quotes highlight the dual challenges (epistemic and incentive) facing the U.S. intervention in Afghanistan. One category of challenges related to the constraints facing foreign interveners. A second category of challenges related to constraints facing domestic actors at the national level. This led to a dual set of complex constraints-constrained U.S. interveners interacted with a constrained national administrative structure within Afghanistan, which, together, contributed to failure (see Murtazashvili 2016; Murtazashvili and Murtazashvili 2019, 2020, 2021).

\subsection{Aligning Policy Goals Within and Across Bureaucratic Agencies}

In addition to the knowledge considerations described above, the fact that the governments engaged in foreign intervention often operate through multiple bureaucratic agencies also presents a serious obstacle to the formation of concrete and consistent goals throughout the duration of an intervention. Once nation building became an objective in Afghanistan alongside counter-terrorism operations, it became necessary for individuals operating across and within various U.S. agencies, such as the Department of Defense, the Department of State, and USAID to coordinate their efforts in pursuit of definite policy goals. In addition, other governments, including but not limited to those of the United Kingdom, France, Spain, Italy, Canada, and Japan, were also pursuing their own objectives in Afghanistan. However, evidence from the Afghanistan Papers illustrates how these objectives varied considerably across the many different actors and agencies taking part in the reconstruction effort.

Dan McNeill referred to activities in 2007 as "a loose confederated effort of people trying to make their puzzle piece fit into the larger picture."15 David Marsden, former Deputy Director at USAID, stated that "there were too many organizations so it was very confusing. ... There were strategies all over the place." 16 Another anonymous U.S. researcher concurred, stating that "There were too many people, with too many agendas, and they were not talking to each other." ${ }^{17}$ Others recalled how "the priorities shift constantly based on the person in

14 background_ll_07_xx_xx_undated_mcneill1.

15 background_1l_07_xx_xx_undated_mcneill1.

16 marsden_david_ll_05_a2_12032015.

17 background_ll_01_xx_dc_08042015. 
charge,"18 resulting in "a multiple prioritization of policies and conflicting priorities." are our objectives?” one U.S. military official asked in 2015. "Nation building? Women's rights?"20

At the international level, former National Security Council director for Afghanistan John Wood recognized security sector reform to be "a major problem" on the grounds that "everyone has a piece of the pie but no coherence."21 Wood listed the different responsibilities of six different "lead nations" and noted how they were all left to determine their own "approach.” These approaches "changed frequently," not only making coordination across countries difficult but "none of them [moved] at the same pace" even when other aspects of policy were "lined up." Tim Graczewski, a U.S. Navy Reserve intelligence officer who served as economic development officer in southern Afghanistan, described in a 2015 interview how "there was no master plan" since "every country had their own pet project and lanes of effort."22 A former British official even found that the counter-narcotics and counter-insurgency policies undertaken primarily by the U.K. and U.S. governments proved to be contradictory. ${ }^{23}$ The Afghanistan experience highlights the more general point that when there are numerous aid donors dealing with a single recipient, it can create tensions and contradictions between goals and associated strategies (see Murshed 2009; Murshed and Sen 1995).

\section{Implementation (Selection of Means)}

While the evidence contained within the Afghanistan Papers demonstrates the grave difficulties faced even at the level of selecting and maintaining consistent goals during the U.S.-led intervention in Afghanistan, the challenges continue to mount at the decision node of selecting and implementing the appropriate means to achieve the chosen ends.

Since the correspondence of the means employed and the goals pursued must be evaluated using some criteria of measurement, a government staging a foreign intervention must identify some way to measure output and define what would constitute a successful intervention. The selection and implementation of the

\footnotetext{
18 background_ll_01_xx_dc_11132014.

19 background_ll_03_xx_xx3_08242015.

20 background_1l_01_xx2_dc_02102015.

21 background_ll_04_xx_06172015.

22 graczewski_tim_ll_05_c5_01112015.

23 background_ll_04_xx_09232016.
} 
means and evaluation of the resulting consequences occur through a political process, which poses further challenges due to the incentives inherent within that process.

\subsection{Matching Means with Ends in the Absence of Profit and Loss Feedback}

In his analysis of the industrial organization of government bureaucracy, Mises defines bureaucratic management as the "management of affairs which cannot be checked by economic calculation" (1944: 48). This is contrasted with the operation of the market economy, where profit and loss accounting in terms of money prices permits economic calculation and provides feedback concerning the relative satisfaction of consumer preferences. In this way, economic calculation serves as a means of sorting alternative uses for scarce resources and to filter out uses which are wasteful. Without such a yardstick in the realm of bureaucratic management, the consequences of applying different means in pursuit of some end cannot be measured and compared with reference to a single cardinal number as would be the case with money profits or losses. As a result, a country committed to pursuing an intervention through a government bureaucratic apparatus must rely on alternative metrics to evaluate the correspondence of the means employed to the ends sought.

The failure of U.S. and allied governments to identify and act upon useful metrics is a recurring theme in the Afghanistan Papers. "It was impossible to create good metrics," an unidentified senior National Security Council official admitted in a 2016 lessons learned interview. 24 "We tried using troop numbers trained, violence levels, control of territory and none of it painted an accurate picture," he continued. A senior officer who worked for the U.S. military in Kabul responded in a different interview that "we wanted hard quantitative metrics that would tell us that $x$ project is producing the desired outcomes, but we had a hard time defining those metrics."25

It may not be surprising, then, that a 2008 strategic review of the situation in Afghanistan called the "Lute Review" found there to be "no correspondence between what we [the U.S. government] said our goals were and means we were allocating to achieve them." 26 An anonymous U.S. Special Forces advisor stated in a 2016 interview that the U.S. government was "sending the right talent but in the

24 background_ll_07_xx_dc_09162016.

25 background_ll_07_xx_dc_06302016.

26 background_ll_03_xx_nyc_08272015. 
wrong duty positions," as "people's backgrounds didn't match with the qualifications."27 Ryan Crocker, retired U.S. diplomat and former Ambassador to Afghanistan, believed the failure to attain desired nation-building results in Afghanistan “wasn't a resource thing so much as not marrying up resources and expertise."28

\subsection{Waste, Metrics Manipulation, and Mission Creep}

In the absence of clear metrics to match strategies with policy goals and consequently evaluate their effectiveness, decisions concerning resource allocations were left to the political process and bureaucrats operating within and across several agencies. However, the incentives inherent in these domains, along with the lack of feedback mechanisms regarding the opportunity cost of scarce resources, resulted in massive spending with little accountability. The infusion of money into Afghanistan thus led to waste, fraud, and mission creep.

"How much money was spent starts with Congress," retired U.S. army brigadier general Brian Copes told SIGAR interviewers in 2016. ${ }^{29}$ "Congress gives us money to spend and expects us to spend all of it," he continued. "No one in the military is going to go back and say we really don't need all this money, we only need $x$ amount of money. The attitude became we don't care what you do with the money as long as you spend it.” Multiple interviewees recognized the outsized budgets to be a proxy for political commitment. ${ }^{30}$ A former USAID official recalled how "There was tons of pressure ... to spend as much money, as quickly as possible, but there was effectively no pressure to prove what impact you were having." 31 In this frenzied spending climate, one former forensic operations program manager for an anti-corruption task force found that $18 \%$ of the money tied up in 3,000 contracts under review ended up going to insurgent groups like the Taliban while estimating that $40 \%$ of $\$ 106$ billion went to some combination of transnational crime, insurgency, and government corruption. ${ }^{32}$

Niskanen $(1968,1971,1975)$ emphasized that bureaus seek to maximize their discretionary budget-the amount beyond what is necessary to satisfy the

27 background_ll_05_xx_phone_01222016.

28 crocker-ryan_ll_second_interview_12012016.

29 copes_brian_ll_05_c15_02252016.

30 background_ll_01_xx_dc_04242015; background_11_03_xx_dc_12112015.

31 background_ll_07_xx_dc_06012017 On the various challenges and perverse incentives in aid provision, see Easterly 2002, 2006, 2014; Ghani and Lockhart 2008: 85-114; Murshed 2009; Murshed and Sen 1995; Trisko Darden 2019.

32 background_ll_03_xx_dc_10062015. 
demands of the agency's sponsors (i.e., legislators). In the absence of profit and loss, budgets serve as a key means of determining the status and influence of bureaus in the political landscape. Bureaus obtain their resources from legislators who determine the allocation of an overall pool of resources. The result is an intense competition between bureaus who seek to produce observable outcomes to demonstrate their effectiveness and importance to their sponsors. In the context of foreign intervention, this dynamic can manifest itself in a manipulation of available metrics, careless spending, and mission creep that draws resources away from the initial goal and generates conditions under which counterproductive consequences may arise.

Former U.S. lieutenant attorney general and national security advisor Michael Flynn recognized these incentives at work in intelligence agencies, noting that "there is an inherent bias in the intel community because they want to get money, they want to exist, and they want to grow." 33 Meanwhile, a former British official told SIGAR in a 2016 interview that "politically led buzz terms drive agendas" because bureaucracies "see opportunity to build budgets and position from political statements." ${ }^{34}$ Brian Copes likened the huge amounts of money flowing through political channels to be "an addiction that affected every agency." 35 Doug Lute described the mentality within agencies as "if we don't spend, GAO [the Government Accountability Office] or committees on the Hill will stop us from getting funding. This leads to spend, spend, spend." ${ }^{36}$ An anonymous U.S. official and budgeting expert claimed that "the refrain that drove the budgeting process was 'We can't shortchange Afghanistan. It has to be as big as Iraq.,"37

To ensure they receive funding, agencies had to justify their activities by appealing to metrics of some kind. However, these metrics were naturally chosen to make the agencies as a whole as well as those individuals operating within them seem successful. "Every data point was altered to present the best picture possible.," U.S. military advisor Bob Crowley recounted in a 2016 lessons learned interview. ${ }^{38}$ "Surveys, for instance, were totally unreliable but reinforced that everything we were doing was right and we became a self-licking ice cream cone.” A U.S. military officer described how many personnel involved in the intervention recognized this issue and "were also worried about metrics manipulation." 39 As an example, the same officer recalled how "Brigade staff would often make their security situation

33 flynn_michael_ll_11102015.

34 background_ll_04_xx_04062016.

35 copes_brian_ll_05_c15_02252016.

36 lute_doug_ll_01_d5_02202015.

37 background_ll_01_xx_dc_04242015.

38 background_ll_07_xx_woodbridge_08032016.pdf.

39 background_11_07_xx_dc_07112016. 
look awful when they arrived and raise it dramatically as they were leaving to show improvement during their deployment." One NATO official similarly described how "when the metrics started, it was normal for everyone to depict low baselines to give themselves room to grow. But then the games started. We'd get the metrics from the agencies, compile them, prepare to brief the president on them." ${ }^{40}$ Nevertheless, he still believed that "metrics never had an impact on policy."

In the Afghanistan Papers, waste and mission creep were particularly identified in relation to the Commander Emergency Response Program (CERP) and the operations of USAID. A U.S. Army civil affairs officer noted how after the 2009 surge "there was no 'E' in CERP ... in any of the projects we did in Afghanistan." ${ }^{41}$ A former National Security Council staffer regarded CERP as "out of control" and described how, despite the program's original purpose as "a million dollars walking around money" for "patching holes in the street" or "clearing away garbage," the money channeled through CERP ended up "being used to build roads to mega projects" and "clearly led to abuse." 42 An aid coordinator in Kabul described CERP as “out of control until 2010" while it "constructed unused buildings." 43 One U.S. military officer recalled how CERP money was being used to build schools "even though there weren't enough teachers to fill them" and as a result "the buildings languished and some of them even became bomb-making factories." ${ }^{44}$ Doug Lute declared $\$ 1$ billion in CERP money held by the military to be "funny money" that "no one can account for" as a result of a lack of coordination with USAID. ${ }^{45}$ When asked about wasteful spending, an anonymous NATO official called CERP "a dark pit of endless money for anything with no accountability" and recalled that "millions of dollars were committed with such callousness."46

Meanwhile, Brian Copes described USAID as "a government agency that has lost its way" with a mission "to perpetually involve itself in projects to justify its existence." ${ }^{47}$ To Copes, this strategy involved making sure, "locals are dependent on USAID so USAID can continue to exist." One Army civil affairs officer stated that "it was impossible to get a decision out of USAID" and that he was "told to just keep spending." 48 U.S. Army officer Eric Wahner said in a 2015 interview that "USAID was just going to pour money and that's what they were going to do. It was a total

40 background_1l_01_xx_brussels_02232015.

41 background_ll_07_xx_dc_b_07122016.

42 background_ll_01_xx_dc_09162015.

43 background_ll_02_xx_kabul2_01262015.

44 background_ll_07_xx_dc_07112016.

45 lute_doug_1l_01_d5_02202015.

46 background_ll_01_xx_brussels_02242015.

47 copes_brian_ll_05_c15_02252016.

48 background_ll_07_xx_dc_b_07122016. 
waste." ${ }^{49}$ All of this resulted in the allocation of resources towards unsustainable projects that were not responsive to the preferences of the local Afghan population, leading retired U.S. diplomat Richard Boucher to declare that "if there was ever a notion of mission creep it is Afghanistan." 50 The experience in Afghanistan supports the broader point that the international aid system is "now deeply out of synch with the challenges of the contemporary world" (Ghani and Lockhart 2008: 86).

\subsection{The Contracting System in Afghanistan}

Many documents in the Afghanistan Papers contain negative references to the contracting system employed by USAID in the reconstruction effort in Afghanistan. Brian Copes explained in his interview with SIGAR how "USAID built national level contracts and contractors would go out and allegedly do what USAID wants." ${ }^{51}$ As a result, Eric Wahner recalled having "zero interaction with USAID at an administrative level” besides "bumping into their contractors now and then." Michael Callen described how "when it came to the actual boring part about implementation," the U.S. government "was going to contract that to somebody and then they were going to go and do it however they did it. Maybe the[y] would subcontract it to someone or not."52

One former senior U.S. official relayed in a lengthy interview response the incentives inherent within the contracting system and the waste that followed: ${ }^{53}$

The money flows from appropriations to USAID to Mission Director to divisions, and now they have to spend that money. They can't do a lot of small projects because these take as much time as big projects. So then big contracts go to Chemonics, DAI, etc. They subcontract to smaller companies who subcontract to Afghan NGOs who subcontract to local contractors. $20 \%$ is taken out for overhead at every step. The local engineer hired to implement the project knows his incentives. Everyone is under pressure to spend money so he can inflate his budget. He can get second-rate materials because no one will check the work (or he can likely pay off inspectors). He will hire family to do the work. He, and every other contractor, is graded not on quality but on how many schools he builds, because ultimately this is the metric demanded in Washington. Therefore, he has little incentive to coordinate with local communities, other donors, or the local government. Just get the schools built so he can get the next contract. In addition, he doesn't know how long the money will continue to flow, and he has many people in his family and community depending on him and telling him that it is his responsibility to make money now to support the rest of them when things go bad again. So, even for honest contractors, the incentives are for expensive, shoddy, uncoordinated, quickly built schools. And that is often what we got.

49 wahner_eric_1l_05_c2_01052015.

50 boucher_richard_ll_01_b9_10152015.

51 copes_brian_ll_05_c15_02252016.

52 callen_michael_ll_02212018.

53 background_ll_03_xx_dc_12112015. 
Jeff Raleigh, former communications officer and counsel at the U.S. embassy in Kabul, recounted a time when he was "sitting in a meeting about schools with the representative of the contractor who was building schools. One of the roofs had collapsed. USAID said that they had built it wrong, so we have to rebid it. I said, wait, can't we get the money back? That's the way it would normally work." 54

Contracts often cannot be written in a manner that completely specifies all aspects of desired quality (Hart 1989; Hart and Moore 1999; Hart, Shleifer, and Vishny 1997; Tirole 1999). Incomplete contracts, combined with asymmetric information, create principal-agent problems and incentives for contractors to act opportunistically (Miller 1992; Williamson 1993). In the context of contracting in Afghanistan, these principal-agent problems are especially severe because the principals are bureaucrats largely disconnected from the communities receiving the final product or service (Murtazashvili 2016).

Further compounding these issues are a variety of factors which exacerbate the principal-agent problem (see Murshed 2009; Murshed and Sen 1995). For example, there may be numerous principals (e.g., the different donor agencies discussion in Section 2.2) with conflicting objectives who are dealing with a single agent in a recipient country. Because there are many principals (donors) dealing with a single agent (aid recipient), it may be the case that each principal is unable to offer sufficient incentives for the agent to carry out their preferred task. Further, where agents (aid recipients) with many principals undertake multiple nuanced tasks, they can shirk on tasks they value less while focusing on those they value more. Alternatively, agents may engage in cheap talk where they signal that they will engage in the manner desired by donors but fail to follow through. Moreover, considering the case of the donor country, it is often difficult for those whose interests bureaucrats represent-U.S. legislators and their constituents-to directly observe bureaucratic behavior and provide feedback (see Coyne 2008a, 2008b, 2013). In the face of soft budget constraints and a disconnect between service providers and consumers, bureaucrats have very little incentive to discover ways to alleviate these numerous agency problems.

According to Richard Boucher, Afghans would tell him that only $10-20 \%$ of the money originally appropriated reaches Afghanistan "and less than $10 \%$ ever gets to a village" after going through "a bunch of expensive American experts" in the beltway. ${ }^{55}$ So while U.S. personnel may tell local Afghans that they spent $\$ 1$ billion in total, Afghans would see only $\$ 50$ million worth of roads by the end of the subcontracting process described above. Ashraf Ghani, former Minister of Finance

54 raleigh_jeff_ll_05_d5_unredacted_11282017.

55 boucher_richard_ll_01_b9_10152015. 
and later President of Afghanistan, apparently recognized this situation early on and expressed his belief that "the U.S. should just give the money to the Afghans and they will build the roads and will likely do it at one-tenth of the cost."56 However, Ghani was reportedly told the U.S. government "was not comfortable just writing [a] check and saying, go forth, do it." Instead, the intervention relied upon, in the words of Newt Gingrich in a 2002 email to Donald Rumsfeld, a "slow, laborious bureaucratic red tape ridden" process to fulfill intended nation-building objectives in Afghanistan. ${ }^{57}$

\section{System Effects (Realization of Ends)}

Human societies are characterized by numerous overlapping complex systems. Complex systems are defined by two features-(1) the elements within the system are interconnected such that intervening upon one element generates changes in other parts of the system and (2) the system as a whole demonstrates behaviors and patterns that differ from its component parts. Complex systems cannot be designed and implemented as if they are simple linear and additive scenarios (Hayek 1967; Potts 2000; Wagner 2016, 2020). Those engaging in foreign intervention by means of top-down planning tend to treat the foreign society in which they are operating as a linear system in which an intended outcome can be attained directly following the implementation of those means presumed to be appropriate. ${ }^{58}$ The treatment of complex systems as if they were simple systems results in "system effects," which refer to unanticipated and often unknowable consequences of an initial action (Friedman 2014; Jervis 1997).

System effects emerge from three sources (Jervis 1997: 10-27). First, interventions have direct and indirect effects. Direct effects are those related to the immediate target of the interventions. Indirect effects are those outside of the immediate target and emerge as people respond to the new incentives created by the intervention. The emergence of indirect effects can be immediate or long and variable. In Afghanistan, for instance, one senior USAID official stated that the infusion of money "drove instability," recognizing that "every time we threw money at a system, we destroyed it or made it worse." ${ }^{59}$ Elsewhere in the same interview, the official described how "funding exacerbated every problem and created countless new ones.” U.S. Army brigadier general J.B. Vowell recalled in a

56 background_ll_01_xx_dc_08252015.

57 snowflake_gingrich_roads_nsarchive_09302002.

58 For a detailed discussion of the issues contributing to expert failure, see Koppl 2018.

59 background_ll_07_xx_nvirginia_08152016. 
2017 interviewee with SIGAR that "there were unforeseen consequences in everything we did."60 One example he gave involved CERP re-igniting "a 400 year animosity over a bride-napping" that "took months ... to figure out what had gone wrong." Thomas Johnson recalled how the workers in a ditch-digging program were arbitrarily paid around $\$ 100$ a month despite the salary range for local school teachers being only between $\$ 60$ and $\$ 80$ per month. ${ }^{61}$ As a result, "all the school teachers quit their jobs and joined the ditch diggers.” Looking back, Johnson stressed the importance of knowing "the actual specifics of a village economy ... before you try to intervene into that village economy because you can have a really detrimental impact.”

Second, since complex systems involve numerous interacting elements, outcomes are not purely the result of the interactions between two actors but also with interactions with others in the system. Brian Copes noted how the contractors eventually hired to operate in Afghanistan "had to pay off [insurgent group] HIG (Hezb-e Islami Gulbuddin) or to [the] mob to not disrupt projects" and "that is why there was shoddy work and construction."62 Meanwhile, Thomas Johnson described how U.S. personnel were "used by the tribes." ${ }^{33}$ According to Johnson, some tribes would report their traditional tribal enemies as Taliban so that the U.S. military would take them to Gitmo. Johnson recognized how the U.S. would "lose [the support of a] village forever" if such an abduction or the accidental killing of an innocent child or woman occurred at the hands of U.S. personnel.

Finally, complex systems are not linear or additive, which means outcomes are not the result of simple summation of individual elements within the system. Therefore, simply adding more resources or effort in planning is no guarantee of obtaining the desired goal. Many SIGAR lessons learned interviewees described the U.S. approach towards nation-building in Afghanistan as simply throwing money and personnel at problems. One U.S. Special Forces advisor recounted the prevailing mentality as "if we throw enough people at it, it's somehow going to get done." ${ }^{64}$ Ashraf Ghani reportedly said that "the Afghan capacity to absorb money was \$2 billion a year, max" and that "everything else was wasted money." 65 Nevertheless, a former National Security Council staffer reported that "by 2007 the money was flowing fast and furious. We were in crisis management mode and we were dumping more money into the country than it could possibly absorb." 66

60 vowell_jb_ll_07_45_03212017.

61 johnson_thomas_ll_01072016.

62 copes_brian_ll_05_c15_02252016.

63 johnson_thomas_ll_01072016.

64 background_ll_05_xx_phone_01222016.

65 background_ll_01_xx_xx_10012014.

66 background_ll_01_xx_phone_01052015. 
Likening the U.S. approach towards spending in Afghanistan to pouring water down a funnel, David Marsden said the "massive amounts of people and money going into Afghanistan" amounted to pouring water too fast into the funnel and "flooding the ground." 67 To Marsden, the idea that "more money and more people can accomplish things faster ... couldn't apply in Afghanistan," with the "overflow of money” enabling “corruption.”

\subsection{Corruption}

A number of Afghanistan Papers interviewees report how the intervention in Afghanistan facilitated the creation of a complex system of kleptocracy alongside daily instances of fraud and corruption at all levels of society. In describing the state of mind of Afghans in the south, Thomas Johnson recalled how "we just let [them] rip us off, and I really don't know why. ... [they] got into this whole mind set that ... the American's are here basically to ... feed our pockets." ${ }^{68}$ Gert Berthold, former forensic operations program manager for an anti-corruption task force in Afghanistan, described a "pretty simple" dynamic by which agencies would give Afghans the fuel they ask for and "then lose visibility" before "Afghans would then ask for more."69 A former senior U.N. official described a scam where Afghans "would get trained for two weeks, get their uniforms, then go back to the province and sell them. They would then come back to do it again."70

Michael Flynn vividly described one story he became aware of involving an interpreter who became rich by lying to military commanders and pocketing extra money: ${ }^{71}$

So this commander is using this interpreter and the commander says I need 'this' to this Afghan guy he is talking to. The commander says that he will buy 'it' from you. The man [who is selling the item] says he will sell the item for a couple of hundred dollars. The interpreter then says [to the commander] $\$ 20,000$. The commander says, okay, no problem. The interpreter gives the man a few hundred dollars and the takes the rest of it because he is a savvy businessman. He keeps doing that and keeps doing it and doing it. The money is more and more and he is cutting deals. Everybody loves this interpreter. Everybody thinks the world of him. He drives around in a big up-armored SUV inside of Kabul today. He has security all over him and if you want to rent a nice, clean SUV, black, [and] everybody does, you will rent it from his company. He also owns a couple of banks. That is a real story and a real person. He is

67 marsden_david_1l_05_a2_12032015.

68 johnson_thomas_ll_01072016.

69 background_ll_03_xx_dc_10062015.

70 background_1l_03_xx_xx_08262015.

71 flynn_michael_ll_11102015. 
all of 34 of 35 [years old] as of today. How many others of him are there? There are probably hundreds of those types of individuals who benefited because, frankly, we didn't know what we were doing.

An unidentified former USAID official recounted a similar story where a translator "set up a series of shell companies to bid against each other for PRT contracts at artificially high prices. He was savvy enough to use his time as a PRT employee to learn the ins and outs of the contracting process and then used it to his advantage.,72

Barnett Rubin, former State Department Advisor and academic expert on Afghanistan, reportedly once rhetorically asked former Special Envoy for Afghanistan and Pakistan Richard Holbrooke if he knew what was "the main source of corruption in Afghanistan" before answering "us."73 Brian Copes expressed first-hand experience of such corruption, recounting how an individual whose identity was later redacted showed him a map "where all the roads were constructed" and was told the decision-making process concerning where to place roads "is all corrupt. All the sub governors asked for a road and their contractors benefited from it." 74 However, according to an anonymous State Department official, the U.S. was "so desperate to have the alcoholics at the table, we kept pouring drinks, not knowing [or] considering we were killing them." 75

Ryan Crocker describes being "struck by something [former Afghanistan President Hamid Karzai] said and repeated a number of times" during Crocker's tenure as U.S. Ambassador to Afghanistan. ${ }^{76}$ According to Karzai, "the west led by the US ... had a significant responsibility to bear for the whole corruption issue." Crocker came to agree with Karzai's accusation, telling SIGAR "you just cannot put those amounts of money into a very fragile state and society, and not have it fuel corruption. You just can't.” By the time Crocker gave the interview in 2016, he saw "the deep rooted nature of corruption ... beyond the ability of even a determined Afghan President to correct" and pointed to "the weight of endemic corruption" rather than insurgency as "the ultimate point of failure for [U.S.] efforts."

Christopher Kolenda, a retired U.S. Army colonel who served as strategic advisor to three commanders in Afghanistan, came to understand the system of kleptocracy that developed over time from the initial U.S.-led intervention in 2001. ${ }^{77}$ "By 2006, the Afghan government had self-organized into a kleptocracy,"

72 background_ll_07_xx_dc_06012017.

73 background_ll_03_xx_nyc_08272015.

74 copes_brian_ll_05_c15_02252016.

75 background_ll_03_dc_06172015.

76 crocker-ryan_ll_first_interview_01112016.

77 background_ll_03_xx_dc_04052016. 
he told SIGAR interviewers. He then went on to describe the corruption not as "a classic patronage network" but "a number of senior positions purchased for a price," with the expectation that they could "recoup the cost through cuts from assistant programs, selling uniforms or ammunition on the black market, drug trafficking, or kidnapping.” The retired colonel believed the kleptocracy developed "without anyone's individual agency" and that now "very powerful and wellarmed people wanted to keep it going." He concluded that it was "through sheer naïveté and maybe carelessness that we helped to create the system [of kleptocracy]. Foreign aid is part of how [Afghan officials] get rents to pay for the positions they purchased."

\subsection{Warlords}

The fraud and corruption described above may have resulted unintentionally in many circumstances, but the same cannot be said of the emergence of regional warlords according to firsthand accounts contained within the Afghanistan Papers. Michael Callen recalled in 2015 how "the old hands, the guys who were there in 2003" would "always say to [him] ... that it was pretty clear when the strategy was just going to kind of hand over ministries to people who had standing armies because they could," noting "to them the writing was on the wall right then."78 Indeed, snowflake memos contained within the Afghanistan Papers show Donald Rumsfeld writing to Paul Wolfowitz and Doug Feith on the topic of supporting Afghan warlords. "It seems to me the interagency group ought to have a plan for how we are going to deal with each of these warlords," Rumsfeld wrote to Wolfowitz in April 2002. ${ }^{79}$ This would involve planning "who is going to get money from whom, on what basis, in exchange for what, what is the quid pro quo, etc." Meanwhile, Rumsfeld tasked Feith with finding out "what kind of assistance the US, any agency or department, is giving each of the warlords and what we are giving Karzai to distribute around the country. We need to see what that balance is." 80

One Afghan official stated that while "the U.S. built civil society" in Afghanistan, "there was no oversight, so the funds were misused" and "even USAID ... gave contracts to particular people - warlords, who got rich."81 "We were giving contracts out to pretty nasty people," a former senior U.S. official admitted,

78 callen_michael_ll_02212018.

79 snowflake_warlords_wolfowitz_04012002.

80 snowflake_warlords_feith_nsarchive06262002.

81 background_ll_03_xx_kabul3_10202015. 
“empowering people we shouldn't have empowered in order to achieve our goals." ${ }^{2}$ This caused "massive resentment among the Afghan people" and led to the U.S. having "no credibility on the corruption issue."

Barnett Rubin told SIGAR in 2015 that construction deals, "including [the] Embassy and the various military bases around the country, ... had nothing to do with the private sector" but "were sweetheart deals with warlords," many of whom "became multi-millionaires overnight" and "had access and control" in Afghanistan. ${ }^{83} \mathrm{~A}$ former USAID official said that "even the PRT leaders were paying off the local warlord to protect the base," since "the base took its first incoming [attack] in something like 18 months" when they once stopped paying. ${ }^{84}$ "The ends had to justify the means," a different USAID official recounted, and so "if [the U.S.] had to work with the bad guys to get things accomplished then so be it."

The Afghanistan Papers present a negative image of warlords. It is important to note, however, that understanding the general category of "warlords" requires nuance. As Mukhopadhyay $(2009,2014)$ shows through first-hand interviews, not all warlords are the same. Her research demonstrates that in certain instances Afghan warlords have effectively provided security, reconstruction, and counternarcotics. As a result, she concludes that in some cases a "hybrid model" of governance, which combines formal institutions and informal governance, may be the most viable alternative among feasible options.

\subsection{Narcotics}

The rise of the warlords and facilitation of corruption in Afghanistan did not occur in isolation but were instead intimately tied up with the simultaneous boom in the narcotics industry (see Coyne, Hall Blanco, and Burns 2016). As poppy cultivation soared following the U.S. intervention, Ashraf Ghani blamed the U.S. for "being in bed with warlords and [giving] them space [to] perpetuate this kind of behavior."86 At the same time, a project intended to improve irrigation "ended up enabling poppy growing” according to a senior State Department official. ${ }^{87}$

"I don't think the U.S. role worked" Doug Wankel, former DEA agent and director of the counter-narcotics task force at the U.S. embassy in Kabul, told SIGAR in $2016 .{ }^{88}$ While he believed corruption to be "the biggest problem" in

82 background_ll_03_xx_dc_12112015.

83 rubin_barnett_ll_05_e2_11062015.

84 background_1l_07_xx_dc_06012017.

85 background_ll_03_xx_xx3_08242015.

86 background_ll_01_xx_phone_09142015.

87 background_ll_01_xx_dc_09232014. 
Afghanistan, drugs became "a nasty thing that had to be contended with" and was "part of" the corruption. Michael Flynn observed in 2015 that "the narcotics today is the worst it has ever been" and said the narcotics industry "has been progressively ... moved up" every year of the intervention. ${ }^{89}$

"We stated that our goal is to establish a 'flourishing market economy" Doug Lute told SIGAR interviewers, but he believes the U.S. "should have specified a flourishing drug trade" since "this is the only part of the market that's working."90

\section{Conclusion}

Evidence from the Afghanistan Papers demonstrates how key aspects of the "fatal conceit of foreign intervention" contributed to the failure of U.S.-led nationbuilding efforts in Afghanistan. From the start, American intervention in Afghanistan faced serious epistemic (knowledge constraints) and incentive problems (political constraints), while the attempt to intervene upon and construct complex systems resulted in a variety of system effects. The first-hand accounts contained within the Afghanistan Papers illuminate how these various dynamics operated and contributed to dysfunction and failure.

Our analysis has two main implications. First, the costs and adverse consequences of the war in Afghanistan have systemic causes. In Afghanistan, binding epistemic and incentive issues faced both international interveners and domestic bureaucrats at both the national and regional levels. This means that we should expect similar results in other foreign interventions where the same institutions and approaches to designing and implementing interventions are employed. Further, it means that any internationalist approach will presume more agency on the part of foreign interveners than what exists in practice due to constraints internal to the society being intervened upon. In the Afghanistan intervention, many of the issues stemmed from a pre-existing administrative structure that limited what could be achieve in practice. It also means that simply placing different leaders in charge of these interventions or tweaking tactics on the margin is unlikely to alleviate such problems. Instead, avoiding these problems would require a fundamentally different institutional approach that appreciates the epistemic and incentive problems discussed above. If such alternative institutional approaches are not feasible, refraining from certain types of foreign interventions needs to be seriously considered.

88 background_1l_04_xx2_04192016.

89 flynn_michael_ll_11102015.

90 lute_doug_ll_01_d5_02202015. 
The evidence provided by the Afghanistan Papers likely understates the magnitude of the constraints involved in foreign intervention. The interviews provide a window into some aspects of the intervention, a window that is U.S.centric and limited to a relatively small number of people. Therefore, a discussion of the nuances and realities from the perspective of local Afghan citizens and practitioners is missing. What the Afghanistan Papers do provide is insight into the perspective of a sample U.S. policymakers and analysts and some of the key patterns and constraints facing foreign interventions.

Second, our analysis suggests that government secrecy exacerbates the fatal conceit of foreign intervention by hiding the intervention's consequences from voters. John Sopko, the Special Inspector General for Afghanistan Reconstruction tasked with leading SIGAR, told the U.S. House Foreign Affairs Committee in a January 15, 2020 testimony that "an odor of mendacity" has been evident "throughout the Afghanistan issue" because of "a disincentive really [for U.S. government agencies] to tell the truth. There's an incentive, and it's for many reasons... we've created an incentive to almost require for people to lie" (U.S. Lessons Learned 2020, timestamp of quote is 52:50). The internal interviews with leading officials involved in the intervention in Afghanistan showed an awareness of serious problems that were not publicly acknowledged. Such secrecy and misdirection surrounding the consequences of the war in Afghanistan reflects a broader problem of secrecy in the national security state. This pervasive secrecy exacerbates principal-agent problems inherent in representative government and thereby creates space for opportunism that undermines the interests of legislators and voters, not to mention those living in the societies in which the U.S. forcibly intervenes (Coyne and Hall 2021; Coyne, Goodman, and Hall 2019).

"What did we get for this \$1 trillion effort?” Jeffrey Eggers, retired Navy SEAL and former senior director for Afghanistan and Pakistan, asked in a 2015 interview with SIGAR. "Was it worth \$1 trillion? These conversations are only happening in private." 91 The late-2019 release of the Afghanistan Papers provides an opportunity to more publicly reckon with the results of what is as of 2021 the longest war in U.S. history and fundamentally reconsider the ability of a government in one country to construct liberal institutions in foreign societies in light of the fatal conceit of foreign intervention.

Acknowledgments: We thank attendees of the 2020 Austrian Student Scholars Conference at Grove City College, where an early draft of this paper was presented, as well as the editor and two anonymous reviewers for comments and helpful suggestions.

91 background_ll_01_xx_dc_08252015. 


\section{References}

\section{Primary Sources}

The Afghanistan Papers. 2019.

The "Afghanistan Papers" refers to a collection of 612 internal documents obtained from the Special Inspector General for Afghanistan Reconstruction (SIGAR) by The Washington Post and released publicly on December 9, 2019. The documents consist of 424 "Lessons Learned" interviews conducted by SIGAR between 2014 and 2018 as well as 188 "snowflake" memos (short internal memoranda) addressed from or to former U.S. Secretary of Defense Donald Rumsfeld between 2002 and 2004.

The collection of documents constituting The Afghanistan Papers is available online: https://www.washingtonpost.com/graphics/2019/investigations/afghanistan-papers/ afghanistan-war-confidential-documents.

Since the documents do not have a uniform format, we include exact document names with links to the corresponding The Washington Post webpage as a footnote for each individual document cited in-text.

\section{Secondary Sources}

"About SIGAR," Special Inspector General for Afghanistan Reconstruction. https://www.sigar. $\mathrm{mil} /$ about/index.aspx?SSR=1.

Beath, A., F. Christia, and R. Enikolopov. 2013. "Empowering Women through Development Aid: Evidence from a Field Experiment in Afghanistan." American Political Science Review 107 (3): 540-57.

Beath, A., F. Christia, and R. Enikolopov. 2015. "The National Solidarity Programme: Assessing the Effects of Community-Driven Development in Afghanistan." International Peacekeeping 22 (4): 302-20.

Berger, D. A. C., W. Easterly, and S. Satyanath. 2013. "Do Superpower Interventions Have Short and Long Term Consequences for Democracy?" Journal of Comparative Economics 41 (1): 22-34.

Bueno de Mesquita, B., and G. W. Downs. 2006. "Intervention and Democracy." International Organization 60 (3): 627-49.

Bush, G. W. 2002. "President Highlights Humanitarian Efforts in Afghanistan.” The White House (Archive). Available online: https://georgewbush-whitehouse.archives.gov/news/releases/ 2002/10/20021011-3.html.

Bush, G. W. 2010. Decision Points. New York, NY: Crown Publishers.

Costs of War. 2019. “U.S. War Spending in Afghanistan FY 2001-2019.” Watson Institute of International and Public Affairs at Brown University. Available online: https://watson.brown. edu/costsofwar/figures/2019/us-war-spending-afghanistan-2001.

Coyne, C. J. 2008a. After War: The Political Economy of Exporting Democracy. Stanford, CA: Stanford University Press.

Coyne, C. J. 2008b. “'The Politics of Bureaucracy' and the Failure of Post-War Reconstruction.” Public Choice 135 (1/2): 11-22. 
Coyne, C. J. 2011. "The Political Economy of the Creeping Militarization of U.S. Foreign Policy."

Peace Economics, Peace Science, and Public Policy 17 (1): 1-25.

Coyne, C. J. 2013. Doing Bad by Doing Good: Why Humanitarian Action Fails. Stanford, CA:

Stanford University Press.

Coyne, C. J., and A. Pellillo. 2011. "Economic Reconstruction amidst Conflict: Insights from Afghanistan and Iraq." Defence and Peace Economics 22 (6): 627-43.

Coyne, C. J., and A. R. Hall. 2021. Manufacturing Militarism: U.S. Government Propaganda in the War on Terror. Stanford, CA: Stanford University Press.

Coyne, C. J., A. Hall Blanco, and S. Burns. 2016. "The War on Drugs in Afghanistan: Another Failed Experiment with Interdiction.” The Independent Review: A Journal of Political Economy 21 (1): 95-119.

Coyne, C. J., and R. L. Mathers. 2010. "The Fatal Conceit of Foreign Intervention." Advances in Austrian Economics 14: 227-52.

Coyne, C. J., N. Goodman, and A. R. Hall. 2019. "Sounding the Alarm: The Political Economy of Whistleblowing in the U.S. Security State." Peace Economics, Peace Science, and Public Policy 25 (1): 1-11.

Denison, B. 2020. "The More Things Change, the More They Stay the Same: The Failure of RegimeChange Operations." Cato Institute Policy Analysis No. 883, https://doi.org/10.1515/peps2018-0024.

Downes, A. B., and J. Monten. 2013. "Forced to Be Free? Why Foreign-Imposed Regime Change Rarely Leads to Democratization." International Security 37 (4): 90-131.

Duncan, T. K., and C. J. Coyne. 2015. "The Political Economy of Foreign Intervention.” In The Oxford Handbook of Austrian Economics, edited by P. J. Boettke, and C. J. Coyne, 679-97. New York, NY: Oxford University Press.

Easterly, W. 2002. The Elusive Quest for Growth. Cambridge, MA: MIT Press.

Easterly, W. 2006. The White Man's Burden: Why the West's Efforts to Aid the Rest Have Done So Much Ill and So Little Good. New York, NY: The Penguin Press.

Easterly, W. 2014. The Tyranny of Experts: Economists, Dictators, and the Forgotten Rights of the Poor. New York, NY: Basic Books.

Enterline, A. J., and J. M. Greig. 2005. "Beacons of Hope? the Impact of Imposed Democracy on Regional Peace, Democracy, and Prosperity.” The Journal of Politics 67 (4): 1075-98.

Enterline, A. J., and J. M. Greig. 2008. "Perfect Storms? Political Instability in Imposed Polities and the Futures of Iraq and Afghanistan." Journal of Conflict Resolution 52 (6): 880-915.

Friedman, J., ed. 2014. Societal Complexity: System Effects and the Problem of Prediction. New York, NY: Routledge.

Ghani, A., and C. Lockhart. 2008. Fixing Failed States: A Framework for Rebuilding a Fractured World. New York, NY: Oxford University Press.

Gant, J. 2014. One Tribe at a Time: The Paper that Changed the War in Afghanistan. New York, NY: Black Irish Entertainment LLC.

Hart, 0. 1989. "Incomplete Contracts." In Allocation, Information, and Markets, edited by J. Eatwell, M. Milgate, and P. Newman, 163-79. London: The Macmillan Press Limited.

Hart, O., and J. Moore. 1999. "Foundations of Incomplete Contracts." The Review of Economic Studies 66 (1): 115-38.

Hart, Ol., A. Shleifer, and R. W. Vishny. 1997. "The Proper Scope of Government: Theory and an Application to Prisons." Quarterly Journal of Economics 112 (4): 1127-61. 
Hayek, F. A. 1967. "The Theory of Complex Phenomena." In Studies in Philosophy, Politics and Economics. London: Routledge.

Hayek, F. A. 1988. The Fatal Conceit: The Errors of Socialism. Chicago, IL: University of Chicago Press.

Jervis, R. 1997. System Effects: Complexity in Political and Social Life. Princeton, NJ: Princeton University Press.

Koppl, R. 2018. Expert Failure. New York, NY: Cambridge University Press.

Miller, G. J. 1992. Managerial Dilemmas: The Political Economy of Hierarchy. Cambridge, UK: Cambridge University Press.

Mises, L. Von. 1944. Bureaucracy. New Haven, CT: Yale University Press.

Mukhopadhyay, D. 2009. “Warlords as Bureaucrats: The Afghan Experience." Carnegie Endowment for International Peace, Carnegie Papers, Number 101. Available online: www. jstor.org/stable/resrep13086 (accessed February 10, 2021).

Mukhopadhyay, D. 2014. Warlords, Strongman Governors and State Building in Afghanistan. New York, NY: Cambridge University Press.

Murshed, S. M., and S. Sen. 1995. "Aid Conditionality and Military Expenditure Reduction in Developing Countries: Models of Asymmetric Information.” Economic Journal 105 (429): 498-509.

Murshed, S. M. 2009. "On the Non-contractual Nature of Donor-Recipient Interaction in Development Assistance.” Review of Development Economics 13 (3): 416-28.

Murtazashvili, I., and J. B. Murtazashvili. 2019. "The Political Economy of State Building." Journal of Public Finance and Public Choice 34 (2): 189-207.

Murtazashvili, J., and I. Murtazashvili. 2020. “Wealth-destroying States.” Public Choice 182 (3-4): 353-71.

Murtazashvili, J. B., and I. Murtazashvili. 2021. Land, the State, and War: Property Institutions and Political Order in Afghanistan. New York, NY: Cambridge University Press.

Murtazashvili, J. B. 2016. Informal Order and the State in Afghanistan. New York, NY: Cambridge University Press.

Niskanen, W. N. 1968. "The Peculiar Economics of Bureaucracy.” The American Economic Review 58 (2): 293-305.

Niskanen, W. N. 1971. Bureaucracy and Representative Government. Chicago, IL: Aldine, Atherton.

Niskanen, W. N. 1975. "Bureaucrats and Politicians." The Journal of Law and Economics 18 (3): 617-43.

Ostrom, E. 2000. “Crowding Out Citizenship.” Scandinavian Political Studies 23 (1): 3-16.

Payne, J. L. 2006. ““Does Nation Building Work?” the Independent Review.” A Journal of Political Economy 10 (4): 597-608.

Pickering, J., and M. Peceny. 2006. “Forging Democracy at Gunpoint.” International Studies Quarterly 50 (3): 539-60.

Potts, J. 2000. The New Evolutionary Microeconomics: Complexity, Competence, and Adaptive Behaviour. Northampton, MA: Edward Elgar.

Tirole, J. 1999. “Incomplete Contracts: Where Do We Stand?” Econometrica 67 (4): 741-81.

Trisko Darden, J. 2019. Aiding and Abetting: U.S. Foreign Assistance and State Violence. Stanford, CA: Stanford University Press.

U.S. House of Representatives Committee on Foreign Affairs Hearings. 2020. "U.S. Lessons Learned in Afghanistan.” Available online: https://foreignaffairs.house.gov/2020/1/u-slessons-learned-in-afghanistan. 
Wagner, R. E. 2016. Politics as a Peculiar Business: Insights from a Theory of Entangled Political Economy. Northampton, MA: Edward Elgar.

Wagner, R. E. 2020. Macroeconomics as Systems Theory: Transcending the Micro-macro Dichotomy. Cham, Switzerland: Palgrave Macmillan.

Williamson, O. E. 1993. “Opportunism and its Critics.” Managerial and Decision Economics 14 (2): 97-107. 